\title{
Biological properties of a neutralized $2.5 \%$ sodium hypochlorite solution
}

\author{
Virginie Aubut, DDS, ${ }^{\mathrm{a}, \mathrm{b}}$ Ludovic Pommel, DDS, ${ }^{\mathrm{b}}$ Bernard Verhille, MS, ${ }^{\mathrm{c}}$ \\ Thierry Orsière, $\mathrm{PhD},{ }^{\mathrm{d}}$ Serge Garcia, $\mathrm{PhD},{ }^{\mathrm{e}}$ Imad About, $\mathrm{PhD},{ }^{\mathrm{a}}$ and Jean Camps, $\mathrm{DDS}, \mathrm{PhD},{ }^{\mathrm{a}}$ \\ Marseille and Neuilly sur Seine, France \\ LABORATOIRE INTERFACE MATRICE EXTRACELLULAIRE BIOMATÉRIAUX (IMEB), UNITÉ DE \\ FORMATION ET LE RECHERCHES (UFR) ODONTOLOGIE, CHAMBRE SYNDICALE NATIONALE DE L'EAU \\ DE JAVEL, AND UNIVERSITÉS AIX-MARSEILLE
}

\begin{abstract}
Objectives. The objective of this study was to evaluate the influence of neutralizing a $2.5 \% \mathrm{NaOCl}$ solution on its cytotoxicity, genotoxicity, and tissue-dissolving potential.

Study design. The cytotoxicity and the genotoxicity of Dakin, a $2.5 \% \mathrm{NaOCl}$ solution, and a neutralized $2.5 \% \mathrm{NaOCl}$ solution were assessed according to ISO 10993 standards. The weight of palatal mucosa samples placed in neutralized $2.5 \% \mathrm{NaOCl}, 2.5 \% \mathrm{NaOCl}$ was recorded over time as well as the $\mathrm{pH}$ of the solutions.

Results. The neutralized $2.5 \% \mathrm{NaOCl}$ solution was 10 -fold more cytotoxic than the $2.5 \% \mathrm{NaOCl}$ solution. None of the solutions was genotoxic. The $2.5 \% \mathrm{NaOCl}$ solution had a better tissue-dissolving capacity than the neutralized $2.5 \% \mathrm{NaOCl}$ solution. The $\mathrm{pH}$ of the $2.5 \% \mathrm{NaOCl}$ solution and neutralized $2.5 \% \mathrm{NaOCl}$ solution decreased from 12 to 9 and from 7.5 to 5.6 , respectively.
\end{abstract}

Conclusion. Neutralizing a $2.5 \% \mathrm{NaOCl}$ solution increased its cytotoxicity, did not induce any genotoxic effect, and reduced its tissue-dissolving ability.

It has been shown in vivo and in vitro that a chemomechanical preparation of the root canal is necessary because the simple mechanical instrumentation of canal walls is not sufficient to reduce the number of bacteria significantly. ${ }^{1,2}$ The root canal irrigants are often chosen according to their antibacterial potential to increase their efficiency. ${ }^{3}$ However, the liquid may be forced inadvertently beyond the apex and lead to severe injuries if not biocompatible. ${ }^{4}$ Therefore, a balance must be found between the antibacterial properties and the biocompatibility of the root canal irrigants. The type of irrigant and the ideal concentration of a sodium hypochlorite solution are still a matter of debate but a 2.5\% $\mathrm{NaOCl}$ solution may be considered as a good compromise between Dakin $(0.5 \%)$ and the $5.25 \% \mathrm{NaOCl}$ solution commonly used in the United States. ${ }^{5}$ Beyond this concentration, the $\mathrm{NaOCl}$ solution is not considered as biocompatible and is not used for endodontic purposes.

The manufacturers add sodium hydroxide to the $\mathrm{NaOCl}$ solution to increase its shelf life. The high $\mathrm{pH}$ of the commercial $\mathrm{NaOCl}$ solutions induces a shift of the hypochlorous acid $(\mathrm{HClO})$ toward its alkaline form: the hypochlorite ion $\left(\mathrm{ClO}^{-}\right)$. Since $\mathrm{HClO}$ has a better antibacterial efficiency than $\mathrm{ClO}^{-}$, using a neutralized $\mathrm{NaOCl}$ solution should theoretically increase its antibacterial efficiency, but also its biocompatibility because of its neutral $\mathrm{pH}^{6}{ }^{6}$ In addition, the lack of sodium hydroxide in the neutralized solution eliminates the risks of possible chemical burns beyond the apex. ${ }^{7}$ This was not the case when a $0.5 \% \mathrm{NaOCl}$ solution was buffered with sodium carbonate at $\mathrm{pH} 9 .{ }^{8}$ However, it has recently been shown that a neutralized $2.5 \% \mathrm{NaOCl}$ solution at $\mathrm{pH} 7.5 \mathrm{might}$ be a good alternative to its unbuffered counterpart. ${ }^{9}$ It has been demonstrated that the $2.5 \% \mathrm{NaOCl}$ neutralized solution, used within 2 hours upon mixing because of the lack of $\mathrm{NaOH}$, presented the same pulp tissue-dissolving capacities after 5 minutes as the unbuffered $2.5 \% \mathrm{NaOCl}$ solution and displayed a higher antibacterial efficiency. ${ }^{9}$ Nevertheless, other properties of the $2.5 \% \mathrm{NaOCl}$ neutralized solution, such as its biocompatibility, should be evaluated because the root canal irrigant may be inadvertently forced beyond the apex and cause severe inju- 
ries. ${ }^{10}$ The biocompatibility of medical devices should be assessed according to ISO standards, which specify that cytotoxicity and genotoxicity are the 2 mandatory primary tests for dental materials. ${ }^{11}$ Besides the biocompatibility issue, it should also be kept in mind that lowering the $\mathrm{pH}$ of sodium hypochlorite may also modify its tissue-dissolving potential and therefore its aggressiveness toward host tissues in cases of iatrogenic perforation. ${ }^{12}$

Therefore, the purpose of this study was to evaluate the cytotoxicity, the genotoxicity, and the tissue-dissolving potential on porcine palatal mucosa of a neutralized $2.5 \% \mathrm{NaOCl}$ solution.

\section{MATERIALS AND METHODS}

\section{Cytotoxicity test}

The test was performed according to ISO standards. ${ }^{13}$ L 929 fibroblasts were cultivated in Minimum Essential Medium (MEM) supplemented with $10 \%$ fetal bovine serum, $100 \mathrm{IU} / \mathrm{mL}$ penicillin, $100 \mu \mathrm{g} / \mathrm{mL}$ streptomycin, and $0.25 \mu \mathrm{g} / \mathrm{mL}$ amphotericin B (BioScience, Walkersville, MD). These cells were plated at 30,000 cells cm$~^{-2}$ in 96-well plates (Falcon 3072, Becton Dickinson, Oxford, UK). The 96-well dishes were then placed into a humid incubator with an atmosphere of $5 \% \mathrm{CO}_{2}, 95 \%$ air, before use. After 24 hours, the medium from the 96-well plates was removed and replaced by $100 \mu \mathrm{L}$ of the test medium. The test medium was obtained by serial dilutions ( $\mathrm{vol} / \mathrm{vol}$ ) of 3 root canal irrigants in culture medium:

- Neutralized $2.5 \% \mathrm{NaOCl}$ solution obtained mixing 3 volumes of $0.2 \mathrm{M} \mathrm{HCl}$ (Sigma Chemical Co., St. Louis, MO) with 1 volume of $10 \% \mathrm{NaOCl}$ (Sigma). ${ }^{9}$

- $2.5 \% \mathrm{NaOCl}$ solution (Sigma)

- Dakin (Cooper, Melun, France)

The 3 liquids were tested undiluted and diluted to $1 / 10$, to $1 / 100$, or to $1 / 1000$. The medium was left 10 minutes in contact with the target cells before performing the test. Each dilution was tested in a separate plate because chloride is volatile and may evaporate, modifying the outcome of the study. A succinyl dehydrogenase assay (MTT) was performed on the 96-well plates after the 10 minutes of incubation (i.e., 24 hours +10 minutes after the beginning of the experiment). The medium was removed and immediately replaced with $100 \mu \mathrm{L} /$ well of $0.5 \mathrm{mg} / \mathrm{mL} \mathrm{3-(4,5-dimethylthiazol-2-}$ yl)-2,(-diphenyl tetrazolium bromide) dissolved in the medium (Sigma). After incubation for 2 hours at $37^{\circ} \mathrm{C}$, the supernatants were discarded, and the formazan crystals were solubilized with dimethylsulfoxide (100 $\mu \mathrm{L} /$ well) (Sigma). The absorbance of each 96-well dish was determined using an automatic microplate spectrophotometer (E 960, Bioblock, Strasbourg, France) at
$550 \mathrm{~nm}$. The absorbance of the wells containing the same medium was calculated against that of the control medium to determine the percentage of cell viability. The positive control was phenol $(0.64 \mathrm{mg} / \mathrm{mL})$ and the negative control was the medium itself. Experiments were done in triplicate.

A 2-way analysis of variance (ANOVA) (factor 1: root canal irrigant, factor 2: dilution) was performed to compare the cytotoxicity of each tested dilution. A post hoc Duncan test was performed to compare the 3 liquids within each dilution. The significance level was set at $5 \%$ for both tests.

\section{Genotoxicity test}

The study was performed according to ISO standards ${ }^{14}$ on human lymphocytes because of its sensitivity. ${ }^{15}$ Fresh whole blood collected by venipuncture $(0.7$ $\mathrm{mL}$ ) was added to vials containing $9.3 \mathrm{~mL}$ of culture medium (X-VIVO 10), supplemented with $1 \%$ phytohemagglutinin (Life Technologies, Paisley, UK), which is a specific mitogen to induce T-lymphocyte proliferation and 1\% heparin (Life Technologies) to prevent blood coagulation. These vials were incubated at $37^{\circ} \mathrm{C}$ in a humidified atmosphere containing $5 \% \mathrm{CO}_{2}$. After 24 hours, serial dilutions of the 3 root canal irrigants were added to the vials. The 3 liquids were tested diluted to $1 / 250,1 / 500$, and to $1 / 1000$. These concentrations were determined from a cytotoxicity study performed on human lymphocytes (data not shown). The positive control was mytomycin $\mathrm{C}(5 \mu \mathrm{g} / \mathrm{mL})$ and the negative control was the medium itself. The vials were then incubated for 20 hours. Then, $50 \mu \mathrm{L}$ of cytochalasin B $(1 \mathrm{mg} / \mathrm{mL})$ (Sigma) was added to each vial. The vials were gently shaken and incubated again for 24 hours.

Sixty-eight hours after starting the experiment, the cells were harvested by centrifugation at $1200 \mathrm{rpm}$ at $20^{\circ} \mathrm{C}$ for 10 minutes. The supernatant was discarded and the T-lymphocytes underwent a mild hypotonic treatment: $5 \mathrm{~mL}$ of $0.075 \mathrm{M}$ potassium chloride was added and vortexed before a second centrifugation at $1200 \mathrm{rpm}$ and $20^{\circ} \mathrm{C}$ for 1 minute. Once the supernatant was discarded, $5 \mathrm{~mL}$ of the fixative solution (3 parts methanol +1 part acetic acid) were added gradually to fix the cells. The fixation step was repeated twice after a 20-minute storage at $4^{\circ} \mathrm{C}$. The vials were then centrifuged a third time for 10 minutes at $1400 \mathrm{rpm}$ and the cells were smeared on precleaned microscope glass slides and air dried. The human T-lymphocytes were colored with GIEMSA and 1000 cells with or without micronluclei were counted per slide under a light microscope. The number of micronuclei per 1000 cells was recorded in a double-blind manner by an experi- 
enced operator and used for statistical analysis. Each experiment was performed in triplicate.

A chi-square test was performed for each dilution to compare the number of micronuclei after exposure to the 3 root canal irrigants and to the negative control.

\section{Tissue-dissolving capacity}

Palatal mucosa was used to simulate the histological effects of a $\mathrm{NaOCl}$ solution forced in an iatrogenic perforation and coming in contact with gingiva. Fullthickness palatal mucosa samples were dissected from 2 pigs within 2 hours after slaughtering. Twenty-four rectangular pieces $(10 \times 5 \mathrm{~mm})$ were obtained and weighted with a precision balance for standardization purpose $(0.25 \pm 0.02 \mathrm{~g})$. The samples were randomly soaked for 120 minutes in microfuge tubes containing 1 $\mathrm{mL}$ of the following solutions $(\mathrm{n}=6$ per liquid): neutralized 2.5\% $\mathrm{NaOCl}, 2.5 \% \mathrm{NaOCl}, \mathrm{NaOH}(\mathrm{pH}$ adjusted to that of the $2.5 \% \mathrm{NaOCl}$ ), and saline as negative control. Dakin was replaced by $\mathrm{NaOH}$ in this part of the study because the influence of $\mathrm{HClO}$ concentration on tissue-dissolving potential has already been reported. On the opposite, the relative importance of each of the 3 components present in $\mathrm{NaOCl}$ solutions $\left(\mathrm{HClO}, \mathrm{ClO}^{-}\right.$, and $\left.\mathrm{NaOH}\right)$ has never been tested.

Every 10 minutes, the samples were blotted dry for 5 seconds and weighted using a precision balance, the $\mathrm{pH}$ of the solution was recorded at room temperature using a $\mathrm{pH}$ meter.

After 120 minutes, the samples were placed in neutral buffered $10 \%$ formalin. After dehydration, the specimens were embedded in paraffin. Routine histological techniques were used to obtain $5 \mu \mathrm{m}$ serial sections, which were stained with hematoxylin-eosin. Histological findings were recorded by 2 independent operators in a blind manner.

Values obtained from the dissolution test and from the $\mathrm{pH}$ analysis were compared using a nonparametric Kruskall and Wallis test. Post hoc analysis was performed using a Tukey test adapted to nonparametric data. The significance level was set at 5\% $(P<.05)$.

\section{RESULTS}

\section{Cytotoxicity}

The 2-way ANOVA showed that the difference was statistically significant for both factors: root canal irrigant $(P<.01)$ and dilution $(P<.001)$ (Table I). The Duncan test showed that Dakin was the least cytotoxic when tested undiluted $(P=.04)$ or diluted to $1 / 10$ and that that the neutral $2.5 \% \mathrm{NaOCl}$ solution was more cytotoxic than the 2 other liquids when tested diluted to $1 / 100(P=.01)$. However, no difference was found among the 3 liquids when tested after their dilution to $1 / 1000$ (nonsignificant).
Table I. Cell viability of L 929 exposed to serial dilutions of 3 root canal irrigants

\begin{tabular}{lccc}
\hline $\begin{array}{l}\text { Cell viability } \\
\text { (\% negative control) })\end{array}$ & \multicolumn{1}{c}{ Dakin } & $2.5 \% \mathrm{NaOCl}$ & $\begin{array}{c}\text { Neutralized 2.5\% } \\
\mathrm{NaOCl}\end{array}$ \\
\hline Undiluted & $19 \pm 3^{\mathrm{a}}$ & $9 \pm 3^{\mathrm{b}}$ & $11 \pm 5^{\mathrm{b}}$ \\
$1 / 10$ & $92 \pm 9^{\mathrm{a}}$ & $11 \pm 4^{\mathrm{b}}$ & $16 \pm 5^{\mathrm{b}}$ \\
$1 / 100$ & $100 \pm 8^{\mathrm{a}}$ & $99 \pm 7^{\mathrm{a}}$ & $20 \pm 6^{\mathrm{b}}$ \\
$1 / 1000$ & $100 \pm 9^{\mathrm{a}}$ & $113 \pm 8^{\mathrm{a}}$ & $115 \pm 9^{\mathrm{a}}$ \\
\hline
\end{tabular}

The analysis of variance showed statistically significant differences among dilutions $(P<.001)$ and liquids $(P<.01)$. Within the same dilution, the groups with the same superscript letter ${ }^{\mathrm{a}, \mathrm{b}}$ were not statistically different.

Table II. Frequencies of binucleated micronucleated human lymphocytes (\%o) after exposure for 48 hours to 3 root canal irrigants

\begin{tabular}{lccccc}
\hline $\begin{array}{l}\text { Root canal } \\
\text { irrigant }\end{array}$ & $\begin{array}{c}\text { Positive } \\
\text { control }\end{array}$ & $\begin{array}{c}\text { Negative } \\
\text { control }\end{array}$ & Dakin & $\begin{array}{c}2.5 \% \\
\text { NaOCl }\end{array}$ & $\begin{array}{c}\text { Neutralized 2.5\% } \\
\text { NaOCl }\end{array}$ \\
\hline $1 / 250$ & $27 \pm 8$ & $7 \pm 2$ & $8 \pm 2$ & $6 \pm 2$ & $8 \pm 2$ \\
$1 / 500$ & $26 \pm 9$ & $7 \pm 3$ & $9 \pm 2$ & $7 \pm 3$ & $7 \pm 2$ \\
$1 / 1000$ & $27 \pm 6$ & $7 \pm 2$ & $7 \pm 2$ & $6 \pm 2$ & $8 \pm 2$ \\
\hline
\end{tabular}

There was no statistically significant difference between the negative control and the 3 root canal irrigants.

\section{Genotoxicity}

None of the root canal irrigant was genotoxic. The binucleated micronucleated rate of lymphocytes of the negative control showing $7 \%$ of multinucleated cells was in agreement with results reported in a metaanalysis. ${ }^{16}$ The positive controls were performed by addition of mitomycin $\mathrm{C}$, which is a well-known clastogen, showed chromosome damage and showed $27 \%$ of multinucleated cells. The chi-square tests did not show any statistically significant difference among the root canal irrigants and the negative control (ns): none were genotoxic (Table II).

\section{Tissue-dissolving capacity}

No weight or $\mathrm{pH}$ variation was observed when the samples were stored in saline showing that the weighing technique was adequate.

A weight loss was observed in the samples stored in $2.5 \% \mathrm{NaOCl}$ and in the neutralized $2.5 \% \mathrm{NaOCl}$ solution, but an increase both in weight and volume was reported for the samples stored in $\mathrm{NaOH}$. The Kruskall and Wallis test showed a statistically significant difference among the sample weights $(P<.01)$ (Fig. 1). The Tukey test ranked the samples by order of increasing weight from the $2.5 \% \mathrm{NaOCl}$ solution (loss of $60 \%$ ), followed by the neutralized $2.5 \% \mathrm{NaOCl}$ solution (loss of $8 \%$ ), to saline (no weight change) and finally to $\mathrm{NaOH}$ (gain of $28 \%$ ).

The $\mathrm{pH}$ of the $\mathrm{NaOH}$ solution as well as that of the saline solution did not vary over time and remained stable respectively at 12 and 7 (Fig. 2). The $\mathrm{pH}$ of the 


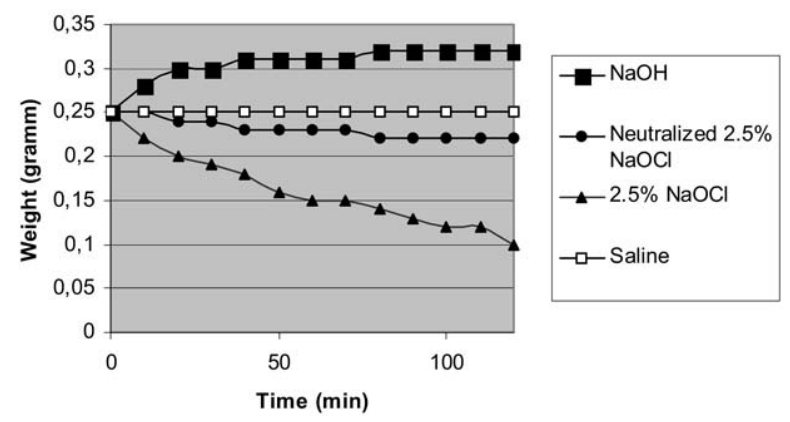

Fig. 1. Weight variation over 120 minutes of palatal mucosa samples placed in $2.5 \% \mathrm{NaOCl}$, neutralized $2.5 \% \mathrm{NaOCl}$, $\mathrm{NaOH}$, and saline. The Kruskall and Wallis test showed a statistically significant difference among the 4 liquids. The samples stored in $\mathrm{NaOH}$ gained weight, those placed in saline did not vary, and those soaked in $2.5 \%$ NaOCL lost more weight than in neutralized $2.5 \% \mathrm{NaOCl}$.

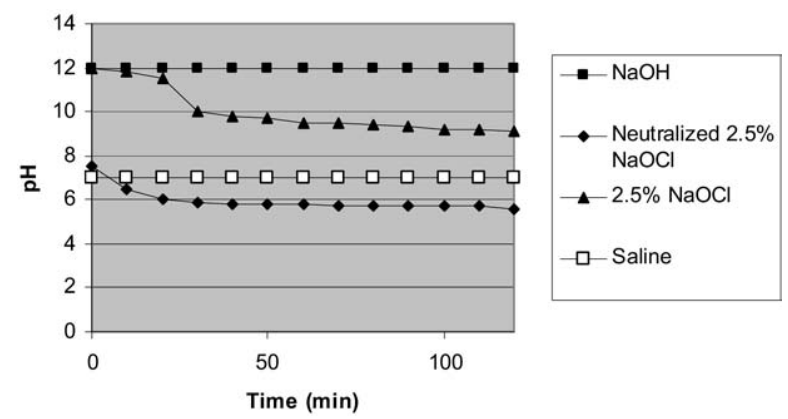

Fig. 2. pH variations over 120 minutes of solutions containing pig palatal mucosa samples. The $\mathrm{pH}$ of saline and $\mathrm{NaOH}$ did not vary but that of the $2.5 \% \mathrm{NaOCL}$ and neutralized $2.5 \% \mathrm{NaOCl}$ solutions decreased respectively from 12 to 9 and from 7.5 to 5.6 .

$2 \mathrm{NaOCl}$ solutions decreased over time from 12 to 9 for the $2.5 \% \mathrm{NaOCl}$ solution and from 7.5 to 5.6 for the neutralized $2.5 \% \mathrm{NaOCl}$ solution.

The histological study of the samples stored in the saline solution showed classical images of a keratinized stratified epithelium with projections into the mucosa underneath. The samples placed in $\mathrm{NaOH}$ showed that the epithelium layer was detached from the underlying connective tissue. It looked like in vesiculo-bullous lesions or superficial burning, but the underlying structures were left intact. This explains that the samples placed in the $\mathrm{NaOH}$ solution gained weight. The samples in $2.5 \% \mathrm{NaOCl}$ and neutralized $2.5 \% \mathrm{NaOCl}$ showed that the epithelium had been totally dissolved. This is directly correlated to the weight loss reported here. For both liquids, the remaining connective tissue was covered by a necrotic layer. The thickness of this necrotic layer was twice larger in the neutralized 2.5\% $\mathrm{NaOCl}$ solution than that in the $2.5 \% \mathrm{NaOCl}$ solution.

\section{DISCUSSION}

\section{Cytotoxicity test}

This work showed that the neutralized $2.5 \% \mathrm{NaOCl}$ solution was the most cytotoxic root canal irrigant because it started to be noncytotoxic after dilution to $1 / 1000$ while Dakin and the $2.5 \% \mathrm{NaOCl}$ solution started to be noncytotoxic when tested diluted respectively to $1 / 10$ and $1 / 100$. In other words, this indicates that there is 1 level of magnitude between the cytotoxicity of Dakin and the $2.5 \% \mathrm{NaOCl}$ solution and also another level of magnitude between the cytotoxicity of the $2.5 \% \mathrm{NaOCl}$ solution and the neutralized $2.5 \%$ $\mathrm{NaOCl}$ solution.

Several studies evaluating the cytotoxicity of various root canal irrigants have already been performed using L 929. ${ }^{17-19}$ The contact time between the liquids and the target cells was reduced to 10 minutes because preliminary studies had shown a great cytotoxic potential of these liquids. Our results are in agreement with previous results according to which a $5 \% \mathrm{NaOCl}$ solution kills $100 \%$ of the target cells within 15 minutes. ${ }^{20}$ Another work had demonstrated that a $0.01 \% \mathrm{NaOCl}$ solution still had effect on the mitochondrial function of human fibroblasts. ${ }^{21}$

The cytotoxicity of the $\mathrm{NaOCl}$ solution increased with concentration because the $2.5 \% \mathrm{NaOCl}$ solution was more cytotoxic than Dakin $(0.5 \% \mathrm{NaOCl}$ solution). This difference was no longer observable with low dilutions $(1 / 1000)$ because cytotoxicity is a dose-dependent phenomenon that does not exist below a threshold specific to each chemical. The reported difference in cytotoxicity, owing to higher concentrations, was expected because it is a general feature of cytotoxicity studies and in accordance with previously reported data. ${ }^{21}$ In case of iatrogenic perforation, the available chlorine concentration of a neutralized $2.5 \% \mathrm{NaOCl}$ solution forced beyond the apex is likely reduced thanks to bleeding caused by tissue dilacerations and to tissue clearance. This likely results in a lower cytotoxicity of the neutralized $2.5 \% \mathrm{NaOCl}$ solution toward the surrounding tissues. More interestingly, the neutralized $1 / 1,1 / 10$, and $1 / 1002.5 \% \mathrm{NaOCl}$ solutions were more cytotoxic than the unbuffered counterparts. Despite the same available chlorine concentration, the chemical composition of the 2 liquids is different in 2 points. First, the neutralized solution does not contain sodium hydroxide and second, the available chlorine is under the form of hypochlorous acid $(\mathrm{HClO})$ in the neutral solution and under the form of hypochlorite ion $\left(\mathrm{ClO}^{-}\right)$ in the unbuffered solution. Sodium hydroxide may act by saponification of fatty acids, ${ }^{22}$ thus participating in the cytotoxic action of the $2.5 \% \mathrm{NaOCl}$ solution. However, the results of the present work showed that this 
effect is limited compared to the action of hypochlorous acid, which easily permeates cell membranes and induces chloramination of proteins resulting in the presence of intracellular organic chloramines that are themselves cytotoxic. A recent and interesting study investigated the intracellular effects of $\mathrm{HClO}$ and clearly demonstrated that it leads to cellular protein aggregation and unfolding. ${ }^{23}$

\section{Genotoxicity test}

Several studies compared the cytotoxicity of various root canal irrigants but few studies reported on the other factors of biocompatibility. One study assessed the inflammatory effects of Dakin when injected in the peritoneal cavity, ${ }^{24}$ whereas another work evaluated the genotoxicity of sodium hypochlorite and concluded to a lack of genotoxicity of the root canal irrigant. ${ }^{25}$ Nevertheless, according to ISO standards, the genotoxicity of dental materials should be evaluated before in vivo testing. ${ }^{11}$ In addition, some studies reported that sodium hypochlorite ${ }^{26}$ and hypochlorous acid ${ }^{27}$ may present a genotoxic potential.

The cytokenesis-blocked micronuleus assay was used here because it is more relevant to work on mammalian cells. Furthermore, the Ames test is not really suitable to test antibacterial substances that are, by essence, cytotoxic toward procaryotic cells. In addition, the cytokenesis-blocked micronuleus assay allows the detection of both clastogenic or aneugenic events. Other authors already used the micronucleus test to assess the genotoxicity of dental materials such as resinous monomers, ${ }^{28}$ siloranes,${ }^{29}$ root canal filling materials, ${ }^{30}$ and dental amalgams. ${ }^{31}$ This test, performed on human lymphocytes, is known to be a robust test for genotoxic assays and provides a reliable index of chromosome breakage and loss. ${ }^{32}$ A guideline for the testing of chemicals using the in vitro mammalian cell micronucleus test, like in the present work, is in preparation by the Organization for Economic Co-operation and Development. This part of the study suggests that the host cells in contact with a neutralized $2.5 \% \mathrm{NaOCl}$ solution are not subject to chromosome alterations.

\section{Tissue-dissolving assay and histological study}

The protocol used for the tissue-dissolving study is derived from previous works using pig palates to assess the tissue-dissolving action of various root canal irrigants. ${ }^{8,33}$ This is clinically relevant because the root canal irrigant may come in contact with gingival or palatal mucosa in cases of iatrogenic perforation of maxillary teeth. Dakin was not used for this part of the work because its histological effects on pig palatal mucosa have already been explored. ${ }^{8}$ However, $\mathrm{NaOH}$ was introduced to evaluate the relative effects of each of the 3 major components of the $\mathrm{NaOCl}$ solutions: $\mathrm{HClO}, \mathrm{ClO}^{-}$, and $\mathrm{NaOH}$. The $\mathrm{pH}$ of the $\mathrm{NaOH}$ solution was adjusted to that of the $2.5 \% \mathrm{NaOCl}$ solution in order to have exactly the same amount of $\mathrm{OH}^{-}$ions.

This part of the work showed that the dissolving action of the $2.5 \% \mathrm{NaOCl}$ solution on pig palatal mucosa is about 5 times higher than that of the neutralized $2.5 \% \mathrm{NaOCl}$. This corroborates the results of nonendodontic studies that have already shown that the optimal $\mathrm{pH}$ region of the antibacterial activity of $\mathrm{NaOCl}$ is around 7.5 but that of the dissolving activity is higher. ${ }^{34}$ The $2.5 \% \mathrm{NaOCl}$ solution is composed mainly of $\mathrm{ClO}^{-}$ ions with a low antibacterial potential but a high dissolving action. On the opposite, the neutralized 2.5\% $\mathrm{NaOCl}$ solution contains $\mathrm{HClO}$ with a high antibacterial potential but a low cleaning activity. ${ }^{35}$ Therefore, the loss of $60 \%$ of weight obtained with the $2.5 \%$ $\mathrm{NaOCl}$ solution compared with the loss of $8 \%$ recorded with the neutralized $2.5 \% \mathrm{NaOCl}$ solution are in agreement with the literature. This study also confirms the results given by Christensen et al., ${ }^{12}$ who demonstrated that a $5.25 \%$ and a $2.6 \% \mathrm{NaOCl}$ solutions presented the same low tissue-dissolving potential when their $\mathrm{pH}$ was adjusted to 6. At $\mathrm{pH} 6, \mathrm{ClO}^{-}$no longer exists and the $\mathrm{NaOCl}$ solution only contains $\mathrm{HClO}$, which has a low dissolving potential even at high concentration. ${ }^{35}$

The histological study showed that the thickness of the necrotic layer was inversely related to weight loss: it was twice larger on the samples placed in the neutralized $2.5 \% \mathrm{NaOCl}$ solution than in the $2.5 \% \mathrm{NaOCl}$ solution. This is likely due to the higher cytotoxicity of the neutralized solution reported in the first part of the study. The histological findings of the study demonstrated that $\mathrm{NaOH}$ has no dissolving potential but causes chemical burnings that cause swelling and protect the underlying tissues. This has already been shown in ophthalmology ${ }^{36}$ and gastroenterology. ${ }^{37}$

No $\mathrm{pH}$ variation was observed with $\mathrm{NaOH}$ because no interaction occurred between the biological tissue and the liquid apart from the initial burning of the superficial epithelium layer. The decrease in $\mathrm{pH}$ was higher for the $2.5 \% \mathrm{NaOCl}$ solution than for the neutralized $2.5 \%$ $\mathrm{NaOCl}$ solution. A high weight loss is associated with a high consumption of $\mathrm{ClO}^{-}$, which is not the case of the $\mathrm{H}^{+}$ ions, which remain unchanged. This combination led to the accelerated decrease in $\mathrm{pH}$ reported here.

This part of the present work suggests that a neutralized $2.5 \% \mathrm{NaOCl}$ solution in contact with palatal mucosa presents a limited aggressiveness toward the surrounding tissues.

The conclusions of the present work are limited to the in vitro conditions of the study and should be confirmed by further in vivo investigations. 
The authors thank Jocelyne Pompili for helpful technical assistance.

\section{REFERENCES}

1. Dalton BC, Ørstavik D, Phillips C, Pettiette M, Trope M. Bacterial reduction with nickel-titanium rotary instrumentation. J Endod 1998;2:763-7.

2. Pataky L, Ivanyi I, Grigar A, Fazekas A. Antimicrobial efficacy of various root canal preparation techniques: an in vitro comparative study. J Endod 2002;2:603-5.

3. Radcliffe CE, Potouridou L, Qureshi N, Habahbeh N, Qualtrough A, Worthington $\mathrm{H}$, et al. Antimicrobial activity of varying concentrations of sodium hypochlorite on the endodontic microorganisms Actinomyces isrealii, A. naeslundii, Candida albicans and Enterococcus feacalis. Int Endod J 2004;37:438-46.

4. Witton R, Henthorn K, Ethunandan M, Harmer S, Brennan PA. Neurological complications following extrusion of sodium hypochlorite solution during root canal treatment. Int Endod $\mathrm{J}$ 2005;38:843-8.

5. Bergenholtz G, Spangberg L. Controversies in endodontics. Crit Rev Oral Biol Med 2004;15:99-114.

6. Zehnder M. Root canal irrigants. J Endod 2006;32:389-98.

7. Kompa S, Redbrake C, Hilgers C, Wustemeyer H, Schrage N, Remky A. Effect of different irrigating solutions on aqueous humour $\mathrm{pH}$ changes, intraocular pressure and histological findings after induced alkali burns. Acta Ophtalmolo Scand 2005;83:467-70.

8. Zehnder M, Kosicki D, Luder H, Sener B, Waltimo T. Tissuedissolving capacity and antibacterial effect of buffered and unbuffered hypochlorite solutions. Oral Surg Oral Med Oral Pathol Oral Radiol Endod 2002;94:756-62.

9. Camps J, Pommel L, Aubut V, Verhille B, Sathoshi F, Lascola B, et al. Shelf life, dissolving action and antibacterial activity of a neutralized 2.5\% sodium hypochlorite solution. Oral Surg Oral Med Oral Pathol Oral Radiol Endod 2009;108:e66-73.

10. Gursoy UK, Bostanci V, Kosger HH. Palatal mucosa necrosis because of accidental sodium hypochlorite injection instead of anaesthetic solution. Int Endod J 2006;39:157-61.

11. ISO Standards 10993-1. Biological evaluation of medical devices. Part 1. Guidance on selection of tests. Geneva; ISO Standardization: 1993.

12. Christensen $\mathrm{C}, \mathrm{McNeal} \mathrm{SP}$, Eleazer P. Effect of lowering the $\mathrm{pH}$ of sodium hypochlorite on dissolving tissue in vitro. J Endod 2008; $14: 449-52$.

13. ISO Standards 10993-5. Biological evaluation of medical devices. Part 5. Tests for cytotoxicity: in vitro methods. Geneva; 1993.

14. ISO Standards 10993-3. Biological evaluation of medical devices. Part 3. Tests for genotoxicity, carcinogenicity and reproductive toxicity. Geneva; 1993.

15. Steiblen G, Orsière T, Pallen C, Botta A, Marzin D. Comparison of the relative sensitivity of human lymphocytes and mouse splenocytes to two spindle poisons. Mutat Res 2005;588:143-51.

16. Fenech M, Wang WP, Kirsch-Volders M, Holland N, Bonassi S, Zeiger E. HUMN project international laboratory comparison of slide scoring for micronuclei and nucleoplasmic bridges in cytokenesisblocked human lymphocytes. Mutat Res 2003;534:45-64.

17. Koualouzidou Z, Margelos J, Beltes P, Kortsaris AH. Cytotoxic effects of different concentrations of neutral and alkaline EDTA solutions used as root canal irrigant. J Endod 1999;25:21-3.

18. Serper A, Calt S, Dogan AL, Guc D, Ozcelik B, Kuraner T. Comparison of the cytotoxic effects and smear layer removing capacity of the oxidative potential water, $\mathrm{NaClO}$ and EDTA. J Oral Sci 2001;43:233-8.

19. Zhang W, Torabinejad M, Li Y. Evaluation of cytotoxicity of MTAD using the MTT-tetrazolium method. J Endod 2003;29: 654-7.
20. Heling I, Rotstein I, Dinur T, Szwec-Levine Y, Steinberg D. Bactericidal and cytotoxic effects of sodium hypochlorite and sodium dichloroisocyanurate solutions in vitro. J Endod 2001; 27:278-80

21. Hidalgo E, Bartolome R, Dominguez C. Cytotoxicity mechanisms of sodium hypochlorite in cultured human dermal fibroblasts and its bactericidal effectiveness. Chem Biol Interact 2002;139:265-82.

22. Estrela C, Estrela CRA, Barbin EL, Spano JCE, Marchesan MA, Pecora JD. Mechanisms of action of sodium hypochlorite. Braz Dent J 2002;13:113-7.

23. Winter J, Ilbert M, Graf PCF, Özcelik D, Jakob U. Bleach activates a redox-regulated chaperone by oxidative protein unfolding. Cell 2008;135:691-701.

24. Tanomaru Filho M, Leonardo MR, Silva LA, Anibal FF, Faccioli FH. Inflammatory response to different endodontic irrigating solutions. Int Endod J 2002;35:735-9.

25. Hagiwara M, Watanabe E, Barrett JC, Tsutui T. Assessment of genotoxicity of 14 chemical agents used in dental practice: ability to induce chromosome aberrations in Syrian hamster embryo cells. Mutas Res 2006;603:111-20.

26. Zavodnik IB, Lapshina EA, Zavodnik LB, Labieniec M, Bryszewska M, Reiter RJ. Hypochlorous acid-induced oxidative stress in Chinese hamster B 14 cells: viability, DNA and protein damage and the protective action of melatonin. Mutat Res 2004;11:39-48.

27. Buschini A, Carboni P, Furlini M, Poli P, Rossi C. Sodium hypochlorite-, chlorine dioxide- and peracetic acid-induced genotoxicity detected by the Comet assay and Saccharomyces cerevisiae D7 tests. Mutagenesis 2004;19:157-62.

28. Schweikl H, Schmalz G, Spruss. The induction of micronuclei in vitro by unpolymerized resin monomers. J Dent Res 2001;80: 1615-20.

29. Schweikl H, Schmalz G, Weinmann W. The induction of gene mutations and micronuclei by oxiranes and siloranes in mammalian cells in vitro. J Dent Res 2004;83:17-21.

30. Schweikl H, Schmalz G. The induction of micronuclei in V79 cells by root canal filling material AH plus. Biomaterials 2000; 21:939-44.

31. Herrstrom P, Bratt I, Holmen A, Hogstedt B. Micronuclei in lymphocyte subsets in relation to plasma mercury, dental amalgam and acrylate-containing tooth fillings. Sci Total Environ 2003;309:253-5.

32. Fenech M. The in vitro micronucleus technique. Mutat Res 2000;455:81-5.

33. Naenni N, Thoma K, Zehnder M. Soft tissue dissolution capacity of currently used and potential endodontic irrigants. J Endod 2004;30:785-7.

34. Urano H, Fukuzaki S. The mode of action of sodium hypochlorite in the cleaning process. Biocontrol Sci 2005;10:21-9.

35. Fukuzaki S. Mechanisms of actions of sodium hypochlorite in cleaning and disinfection processes. Biocontrol Sci 2006;11:147-57.

36. Said D, Dutot M, Labbé A, Warnet JM, Rat P. Ocular burning: rinsing and healing with ionic marine solutions and vegetable oils. Ophtalmologica 2009:223:52-9.

37. Atuq O, Dobrucali A, Orlando RC. Critical pH level of lyes $(\mathrm{NaOH})$ for oesophageal injury. Dig Dis Sci 2009;54:980-7. 